\title{
Tree species diversity and structural composition of village common forest in Bandarban District, Bangladesh
}

\author{
MORGUBATUL JANNAT ${ }^{\star}$, MD. KAMRUZZAMAN, MOHAMMED KAMAL HOSSAIN \\ Institute of Forestry and Environmental Sciences, University of Chittagong. Chittagong-4331, Bangladesh, "email: mjruhin@cu.ac.bd
}

Manuscript received: 23 February 2020. Revision accepted: 1 August 2020.

\begin{abstract}
Jannat M, Kamruzzaman MD, Hossain MK. 2020. Tree species diversity and structural composition of village common forest in Bandarban District, Bangladesh. Asian J For 4: 76-83. Village common forests (VCF) are community-based forest management that has been practiced for a long time in Bangladesh. Currently, this form of forest management is threatened with various anthropogenic factors, urging for study regarding the state of its biodiversity. The study was conducted to explore indigenous tree species diversity of Babu Para village common forest (VCF) in Bandarban District, Bangladesh. Tree species diversity was assessed through stratified random sampling method using sample plots of $20 \mathrm{~m} \times 20 \mathrm{~m}$ in size. Babu Para VCF with an area of 40 acres had more than 406 individuals of 74 tree species belonging to 30 families, including eight unidentified species. Euphorbiaceae and Moraceae were the most dominant families containing 7 species followed by Anacardiaceae ( 5 species), Mimosaceae ( 6 species), and Meliaceae ( 5 specie s). Both the number of tree species and number of individuals decreased regularly with the increase of total height except $\geq 30 \mathrm{~m}$ height range. Number of species and number of individuals was highest in the height range of $(5-<10) \mathrm{m}$. Similar trend was found for dbh $(\mathrm{cm}) \mathrm{class}$ distribution. Both the number of species and number of individuals were highest in the dbh range of $(5-<15) \mathrm{cm}$. Babu Para VCF had diverse floristic resources that were reflected from the Shannon-Wiener's diversity index (3.94), Simpson's diversity index (0.025), Margalef's richness index (12.15) and Species evenness index (0.92). The results depict the presence of rich indigenous tree species diversity in the studied VCF.
\end{abstract}

Keywords: Biological diversity, height class, diameter class, importance value index, indigenous tree species, village common forest

\section{INTRODUCTION}

Village Common Forests (VCFs), also known as Para Reserve, are a sort of common property in Chittagong Hill Tracts (CHT) (Kamruzzaman et al. 2018). The VCFs play important roles in providing pure drinking water, timber, bamboo, fuelwood, leaves, tubers, and fodder, fruits, etc. for community members and their management has set a standard model for the protection of biodiversity, environment, and natural resources. Such common properties have been maintained traditionally for more than hundreds of years (Jannat et al. 2020; Baten et al. 2010).

VCFs are good examples of effective communitybased forest management under certain customary rules and regulations in CHT (Halim and Roy 2006; Baten et al. 2010). Since time immemorial, VCFs have been used by the tribal people for hunting ground, gathering food, swidden cultivation, grazing, charcoal making and collection of minor forest produce including medicinal or herbal produces as major means of livelihood (Roy 2002; Halim and Roy 2006; Chowdhury 2008; Jannat et al. 2018). The VCFs management responsibility belongs to the respective community who depend largely on water sources and forest products to fulfill their basic subsistence requirements and cash income (Miah and Chowdhury 2004; Rasul and Karki 2006; Rasul 2007).

There are no clear statistics about the number and distribution of the VCFs in CHT. An estimation indicated that there are more than $300 \mathrm{VCFs}$ across the region.
Nonetheless, in the last two decades degradation of the forest resources occurred in the VCF due to deforestation, over-extraction of tree and vegetative resources, annual commercial crop cultivation (i.e., ginger, turmeric, etc.), disturbance of the hill slopes by shifting cultivation and horticulture that induced soil erosion. Thus, present study is carried out with an aim to explore tree species diversity of Babu Para Village Common Forest (VCF) in Bandarban District, Bangladesh. The results of this study are expected to provide baseline information for monitoring forest changes in CVFs which serves as reference for management and policies in VCFs in the future.

\section{MATERIALS AND METHODS}

\section{Study area}

The study was carried out in Babu Para VCF, Rowangchhari Sub-district, Bandarban District located in Southeast side of Bangladesh between $21.15^{\circ}$ and $22.20^{\circ} \mathrm{N}$ latitudes and $91.05^{\circ}$ and $92.40^{\circ} \mathrm{E}$ longitudes (Figure 1). Area of Bandarban District is about $4,479 \mathrm{~km}^{2}$ with twothirds of the area are characterized by steep slopes. Bandarban District is not only the most remote district of the country, but also is the least populous (population 292,900) (Jannat et al. 2020). As per the 2011 census, there were 215,934 Bengalis and 142,401 indigenous people in the district. Population density is about $87 / \mathrm{km}^{2}$. The studied VCF was established in 1985 and other relevant information regarding study area is presented in Table 1 . 
Table 1. General information of studied Babu Para VCF in Bandarban District, Bangladesh

\begin{tabular}{ll}
\hline Village & Babu Para \\
\hline Mouza & 9 no. ward \\
Year of village establishment & Alekkhayong mouza \\
Total household (No.) & 1817 \\
Current population of the village (No.) & 20 \\
Year of VCF establishment & 150 \\
Area (Acre) & 1985 \\
Distance (km) from Upazilla & 40 \\
Electricity availability & 42 \\
Drinking water sources & No \\
\hline
\end{tabular}

\section{Methods of sampling}

The methods of the study consisted of reconnaissance surveys, fieldwork, data analysis, and report writing. A pilot survey before main survey (field visits as well as formal discussion with director of Tahzingdong, a NonGovernmental Organization) was conducted to have an idea about location, accessibility, communication means, and VCF area prior to selection of sampling procedure.

Stratified random sampling was carried out for the inventory of the tree species. The whole VCF was divided into three broad areas/blocks considering forest patches having few, medium, and dense tree cover. The sampling plot size for tree species diversity was $20 \mathrm{~m} \times 20 \mathrm{~m}$. A total of 15 randomly selected plots with nearly $3.70 \%$ sampling intensity were surveyed. Area of each plot was demarcated by measuring tape and rope. In each plot, dbh (diameter at breast height; $1.3 \mathrm{~m}$ above the ground) and height of all the trees having $\mathrm{dbh} \geq 5 \mathrm{~cm}$ were recorded. Total height and diameter at breast height (dbh) of all trees inside the demarcated plots were measured using Santo Clinometer and diameter tape respectively. All the tree species in the plots were identified and recorded in local and scientific names. In case of unknown species, plant samples were collected to identify through consulting with taxonomists.

\section{Data analysis}

The value of diversity has a proportional impact on the stability of a plant community (Jannat et al. 2019). There are many indices available which measure species richness and biodiversity. In this study, different phytosociological attributes were calculated for all the plots. These are species relative density, relative frequency, relative dominance and importance value index (IVI) following Chaturvedi and Khanna (1982) and Shukla and Chandal (2000). Four diversity indices, i.e. Shannon-Wiener's index (H), Simpson's diversity index (D), Margalef's species richness index $(\mathrm{R})$ and Species evenness index (E) were analyzed following Shannon and Wiener (1963), Simpson (1949), Margalef (1958) and Pielou (1966), respectively, to get a picture of tree species diversity in Babu para VCF. Empirical data were analyzed using MS Excel.

Density of a species $=$

Total no of individuals of a species in all the quardrats Total no. of quadrats studied

Relative density of a species =

Total No. of individuals of the species

Total No. of individuals of all the species $\times 100$

Frequency of a species $=$

Total no. of quardrats in which the species occurs Total no. of quadrats studied
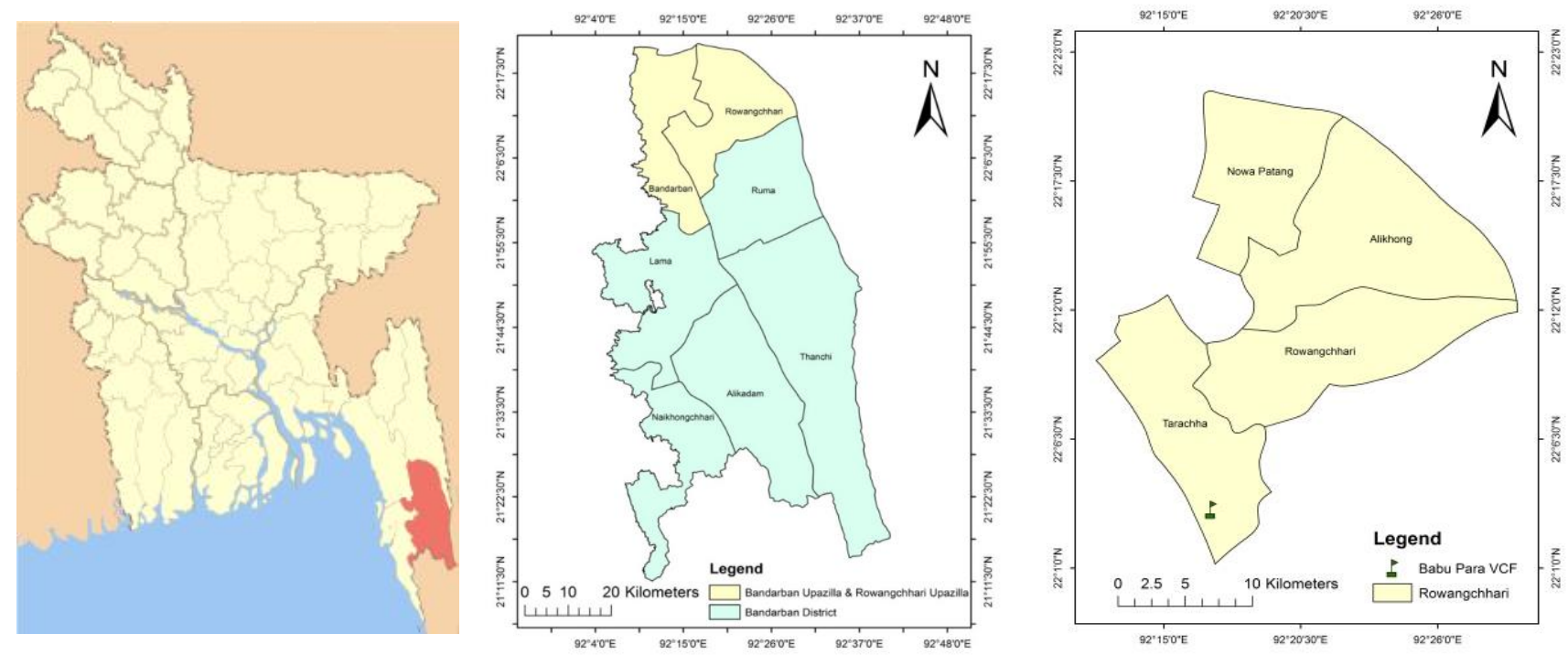

Figure 1. Map of the study area in Babu Para VCF of Bandarban District, Bangladesh 
Relative frequency $=\frac{\text { Frequency of one species }}{\text { Total frequency }} \times 100$

Relative dominance $=\frac{\text { Basal area of one species }}{\text { Total basal area }} \times 100$

IVI = Relative density + Relative frequency + Relative dominance

Shannon-Wiener diversity index (1963) was calculated as the following equation:

$$
\mathrm{H}=-\sum_{i=1}^{n} P_{i} \ln P_{i}
$$

Where,

$\mathrm{H}=$ Shannon-Wiener's diversity index

$\mathrm{P}_{\mathrm{i}}=$ No. of individuals of one species.

One of the best-known diversity indexes based on measures of the quantities of different species in each sample plot is Simpson's index of concentration. Concentration of dominance (D) was measured by using in the calculation of the Simpson's index, which is usually formulated as following equation (Simpson 1949):

$$
\mathrm{D}=\sum P i^{2}
$$

Where,

$$
\begin{aligned}
& \mathrm{P}_{\mathrm{i}}=\mathrm{ni} / \mathrm{N} \text { and } \\
& \mathrm{n}_{\mathrm{i}}=\text { the number of individuals of each species; } \\
& \mathrm{N}=\text { the total number of trees of all species. }
\end{aligned}
$$

Margalef's (1958) index of species richness was calculated by following equation:

$$
\mathrm{R}=(\mathrm{S}-1) / \ln \mathrm{N}
$$

Where,

$\mathrm{R}=$ Species richness index

$\mathrm{S}=$ Total no. of species

$\mathrm{N}=$ Total no. of individuals of all species

Pielous's measure of evenness is as followed (Pielou 1984):

\section{$\mathrm{E}=\mathrm{H} / \ln \mathrm{S}$}

Where,

$\mathrm{E}=$ Species evenness

$\mathrm{H}=$ the Shannon-Weiner Index of Diversity

$\mathrm{S}=$ Total No. of species.

\section{RESULTS AND DISCUSSIONS}

\section{Species composition}

In the sampled sites in Babu Para VCF, there were 406 individuals of 74 tree species belonging to 30 families, including eight unidentified species. Euphorbiaceae and Moraceae were the most dominant family ( 7 species) followed by Anacardiaceae (5 species), Mimosaceae (6 species), and Meliaceae (5 species). Bignoniaceae, Lauraceae, and Verbenaceae family had three species. Remaining families had 1-2 species each (Table 2).

\section{Quantitative structure of tree species}

The study revealed that the highest stem/ha was found for Albizia chinensis (43.33) followed by Gmelina arborea (38.33), Bombax insigne (35.0), Lannea coromandelica (30.0), Oroxylum indicum (25.0) and Protium serratum (25.0). Study revealed that Albizia lucidior occupied the highest basal area $\left(0.47 \mathrm{~m}^{2}\right)$ followed by Toona ciliata $\left(0.24 \mathrm{~m}^{2}\right)$, A. chinensis $\left(0.22 \mathrm{~m}^{2}\right)$, L. coromandelica $(0.21$ $\left.\mathrm{m}^{2}\right)$, and Elaeocarpus tectorius $\left(0.21 \mathrm{~m}^{2}\right)$. The highest relative density was found for $A$. chinensis $(6.40 \%)$ followed by G. arborea $(5.67 \%)$, B. insigne $(5.17 \%)$, L. coromandelica (4.43\%), O. indicum $(3.69 \%)$ and P. serratum $(3.69 \%)$. The highest relative frequency $(5.06 \%)$ was found for $A$. chinensis followed by $G$. arborea (4.28\%), $L$. coromandelica $(3.89 \%)$, B. insigne $(3.5 \%)$, O. indicum $(3.5 \%)$ and $P$. serratum $(2.72 \%)$. Study revealed that $A$. lucidior showed the highest relative dominance $(8.86 \%)$ followed by $T$. ciliata $(4.63 \%)$, A. chinensis $(4.15 \%)$, and L. coromandelica $(4.04 \%)$. It was found that A. chinensis occupied the highest IVI (15.61) followed by G. arborea (12.59), L. coromandelica (12.37), B. insigne (12.16), and A. lucidior (10.13) (Table 3).

\section{Distribution of height $(\mathrm{m})$ and $\mathrm{dbh}(\mathrm{cm})$ classes}

Both the number of species and number of individuals decreased regularly with the increase of total height except at $\geq 30 \mathrm{~m}$ height range. Both the number of species and number of individuals were highest in the height range of $5-<10 \mathrm{~m}$ (Figure 2).

Number of tree species and number of individuals decreased regularly with the increase of total dbh except for $\geq 55 \mathrm{~cm}$ dbh range. Both the number of species and number of individuals were highest in the dbh range of (5$<15$ ) cm (Figure 3).

\section{Diversity indices}

Shannon-Wiener's Diversity Index was 3.94 whereas Simpson's Diversity Index was 0.025. Moreover, Margalef's Richness Index was calculated as 12.15 and Species Evenness Index was 0.92 (Table 4). 
Table 2. Tree species with their local, scientific and family name at Babu Para VCF, Bandarban District, Bangladesh

\begin{tabular}{|c|c|c|c|}
\hline Family & Scientific name & Local name & No. of trees \\
\hline \multirow{5}{*}{ Anacardiaceae } & Lannea coromandelica (Houtt.) Merr. & Bhadi & 18 \\
\hline & Swintonia floribunda Giff. & Civit & 1 \\
\hline & Holigarana longfolia Buch.-Ham. ex Roxb. & Jhawa/Barola & 3 \\
\hline & Spondias pinnata (L.f) Kurz & Jongli amra & 2 \\
\hline & Mangifera sylvatica Roxb. & Uriam & 3 \\
\hline \multirow[t]{2}{*}{ Apocynaceae } & Alstonia scholaris (L.) R. Br. & Chatian & 7 \\
\hline & Holarrhena antidysenterica (L.) Wall. ex Decne & Kuruch & 14 \\
\hline \multirow[t]{3}{*}{ Bignoniaceae } & Fernandoa adenophylla (Wall. ex G.Don) van Steenis & Dakrum & 3 \\
\hline & Stereospermum colais (Buch.-ex Dillw.) Mabberley & Dharmara & 11 \\
\hline & Oroxylum indicum (L.) Kurz & Thona/Kanaidinga & 15 \\
\hline Bombacaceae & Bombax insigne Wall. & Shimul Tula & 21 \\
\hline Burseraceae & Protium serratum (Wall. ex Coelbr.) Engl. & Gutgutia & 15 \\
\hline Caesalpiniaceae & Saraca asoca (Roxb.) de Wild. & Ashok & 4 \\
\hline \multirow{2}{*}{ Combretaceae } & Terminalia bellirica (Gaertn.) Roxb. & Bohera & 3 \\
\hline & Anogeissus acuminata (Roxb. ex DC.) Gull. \& Perr. & Sikori & 9 \\
\hline Dipterocarpaceae & Dipterocarpus turbinatus Gaertn. & Garjan & 2 \\
\hline Ebenaceae & Diospyros sp. & N/A & 4 \\
\hline Elaeocarpaceae & Elaeocarpus tectorius (Lour.) Poir. & Jalpai & 2 \\
\hline \multirow{7}{*}{ Euphorbiaceae } & Antidesma sp. & N/A & 2 \\
\hline & Suregada multiflora (A. Juss.) Bail. & Bon-naranga & 12 \\
\hline & Bridelia sp. & N/A & 2 \\
\hline & Macaranga denticulata (Blume) Mull.-Arg. & Bura & 5 \\
\hline & Gmelina arborea Roxb. & Gamar & 23 \\
\hline & Mallotus tetracoccus (Roxb.). Kurz & Kumari-bura & 1 \\
\hline & Mallotus philippensis (Lamk.) Mull.-Arg. & Sindhuri & 5 \\
\hline Fabaceae & Erythrina fusca Lour. & Mandar & 2 \\
\hline Fagaceae & Lithocarpus sp. & Batna & 3 \\
\hline \multirow{3}{*}{ Lauraceae } & Cinnamomum tamala (Buch.-Ham) Nees \& Eberm. & Jongli Tejpata & 3 \\
\hline & Litsea glutinosa (Lour.) Robinson & Menda & 3 \\
\hline & Litsea monopetala (Roxb.) Pers. & Oirga & 6 \\
\hline Leeaceae & Leea macrophylla Roxb. ex Hornem. & Chaigas & 2 \\
\hline Lythraceae & Lagerstroemia speciosa (L.) Pers. & Jongli Jarul & 2 \\
\hline \multirow{5}{*}{ Meliaceae } & Walsura robusta Roxb. & Bonlichu & 2 \\
\hline & Swietenia macrophylla King & Jongli Mehogoni & 3 \\
\hline & Azadirachta indica A. Juss. & Neem & 2 \\
\hline & Aphanamixis polystachya (Wall.) R.N. Parker & Pitraj & 5 \\
\hline & Toona ciliata $\mathrm{M}$. Roem. & Toon & 3 \\
\hline \multirow[t]{6}{*}{ Mimosaceae } & Albizia chinensis (Osb.) Merr. & Chakua Koroi & 26 \\
\hline & Albizia sp. & Gol koroi & 1 \\
\hline & Albizia lebbeck (L.) Benth. \& Hook. & Kalo Koroi & 1 \\
\hline & Albizia procera (Roxb.) Benth & Koroi & 8 \\
\hline & Albizia odoratissima (L.f.) Benth. & Tetua Koroi & 3 \\
\hline & Albizia lucidior (Steud.) I.C.Nielsen & Sil Koroi & 2 \\
\hline \multirow[t]{7}{*}{ Moraceae } & Ficus pyriformis Hook. \& Arn. & Bon Dumur & 5 \\
\hline & Ficus benghalensis $\mathrm{L}$. & Bot & 6 \\
\hline & Artocarpus chama Buch.-Ham. ex Wall. & Chapalish & 5 \\
\hline & Ficus hispida L.f. & Dumur & 9 \\
\hline & Ficus sp. & Ficus sp. & 2 \\
\hline & Ficus racemosa $\mathrm{L}$. & Jogya Dumur & 4 \\
\hline & Streblus asper Lour. & Sheora & 2 \\
\hline Myristicaceae & Myristica linifolia Roxb. & Amberala & 3 \\
\hline \multirow[t]{2}{*}{ Myrtaceae } & Syzygium cumini (L.) Skeels & Jam & 1 \\
\hline & Syzygium fruticosum (Wall.) Masamune & Putijam & 4 \\
\hline Rhizophoraceae & Carallia brachiate (Lour.) Merr. & Keubong & 2 \\
\hline Rubiaceae & Hymenodictyon orixensis (Roxb.) Mabb. & Ful Gamari & 4 \\
\hline & Neolamarckia cadamba (Roxb.) Bosser & Kadam & 4 \\
\hline Rutaceae & Zanthoxylum rhetsa (Roxb.) DC. & Bajna & 2 \\
\hline Sonneratiaceae & Duabanga grandiflora (Roxb. ex DC.) Wall. & Bandorhola & 12 \\
\hline Sterculiaceae & Sterculia villosa Roxb. ex Smith & Udal & 4 \\
\hline Theaceae & Schima wallichii (DC.) Korth. & Kanak & 5 \\
\hline Tiliaceae & Grewia nervosa (Lour.) Panigr. & Assargula & 8 \\
\hline & Brownlowia elata Roxb. & Moos & 10 \\
\hline Ulmaceae & Trema orientalis (L.) Blume & Banjiyal/Banjiga & 6 \\
\hline Verbenaceae & Callicarpa macrophylla Vahl & Boro Bormala & 10 \\
\hline & Vitex peduncularis Wall. ex Schauer & Goda/Arsol & 2 \\
\hline & Tectona grandis L.f. & Segun & 2 \\
\hline Unidentified & Unidentified-1 & Damka & 4 \\
\hline & Unidentified-2 & Eidgas & 2 \\
\hline & Unidentified-3 & Jati & 4 \\
\hline & Unidentified-4 & Puronja & 9 \\
\hline & Unidentified-5 & Rangma & 6 \\
\hline & Unidentified-6 & $\mathrm{X}$ & 1 \\
\hline & Unidentified-7 & $\mathrm{Y}$ & 3 \\
\hline & Unidentified-8 & $\mathrm{Z}$ & 1 \\
\hline
\end{tabular}


Table 3. Stem/ha, basal area, relative density, relative frequency, relative dominance and Importance Value Index

\begin{tabular}{|c|c|c|c|c|c|c|}
\hline Scientific name & Stem/ha & $\mathbf{B A}\left(\mathbf{m}^{2}\right)$ & RD (\%) & RF (\%) & RDo (\%) & IVI \\
\hline Myristica linifolia & 5.00 & 0.05 & 0.74 & 1.17 & 0.89 & 2.80 \\
\hline Antidesma sp. & 3.33 & 0.01 & 0.49 & 0.78 & 0.12 & 1.39 \\
\hline Saraca asoca & 6.67 & 0.01 & 0.99 & 1.17 & 0.10 & 2.25 \\
\hline Grewia nervosa & 13.33 & 0.01 & 1.97 & 1.95 & 0.19 & 4.10 \\
\hline Zanthoxylum rhetsa & 3.33 & 0.06 & 0.49 & 0.39 & 1.23 & 2.12 \\
\hline Duabanga grandiflora & 20.00 & 0.12 & 2.96 & 2.33 & 2.21 & 7.50 \\
\hline Trema orientalis & 10.00 & 0.01 & 1.48 & 1.56 & 0.07 & 3.10 \\
\hline Lithocarpus sp. & 5.00 & 0.03 & 0.74 & 0.78 & 0.62 & 2.14 \\
\hline Lannea coromandelica & 30.00 & 0.21 & 4.43 & 3.89 & 4.04 & 12.37 \\
\hline Terminalia bellirica & 5.00 & 0.03 & 0.74 & 1.17 & 0.65 & 2.56 \\
\hline Ficus pyriformis & 8.33 & 0.02 & 1.23 & 1.56 & 0.35 & 3.14 \\
\hline Walsura robusta & 3.33 & 0.02 & 0.49 & 0.78 & 0.44 & 1.71 \\
\hline Suregada multiflora & 20.00 & 0.01 & 2.96 & 3.11 & 0.21 & 6.27 \\
\hline Callicarpa macrophyla & 16.67 & 0.04 & 2.46 & 1.95 & 0.74 & 5.15 \\
\hline Ficus benghalensis & 10.00 & 0.14 & 1.48 & 1.56 & 2.67 & 5.71 \\
\hline Bridelia sp. & 3.33 & 0.01 & 0.49 & 0.39 & 0.25 & 1.13 \\
\hline Macaranga denticulata & 8.33 & 0.03 & 1.23 & 1.56 & 0.50 & 3.28 \\
\hline Leea macrophylla & 3.33 & 0.07 & 0.49 & 0.78 & 1.34 & 2.61 \\
\hline Albizia chinensis & 43.33 & 0.22 & 6.40 & 5.06 & 4.15 & 15.61 \\
\hline Artocarpus chama & 8.33 & 0.03 & 1.23 & 1.17 & 0.59 & 2.99 \\
\hline Alstonia scholaris & 11.67 & 0.01 & 1.72 & 1.56 & 0.26 & 3.54 \\
\hline Swintonia floribunda & 1.67 & 0.02 & 0.25 & 0.39 & 0.35 & 0.99 \\
\hline Fernandoa adenophylla & 5.00 & 0.04 & 0.74 & 0.78 & 0.69 & 2.21 \\
\hline Stereospermum colais & 18.33 & 0.20 & 2.71 & 2.72 & 3.77 & 9.20 \\
\hline Diospyros sp. & 6.67 & 0.03 & 0.99 & 1.17 & 0.49 & 2.64 \\
\hline Ficus hispida & 15.00 & 0.02 & 2.22 & 2.33 & 0.46 & 5.01 \\
\hline Ficus sp. & 3.33 & 0.02 & 0.49 & 0.39 & 0.43 & 1.31 \\
\hline Hymenodictyon orixensis & 6.67 & 0.02 & 0.99 & 1.17 & 0.38 & 2.53 \\
\hline Gmelina arborea & 38.33 & 0.14 & 5.67 & 4.28 & 2.64 & 12.59 \\
\hline Dipterocarpus turbinatus & 3.33 & 0.10 & 0.49 & 0.78 & 1.84 & 3.11 \\
\hline Vitex peduncularis & 3.33 & 0.01 & 0.49 & 0.78 & 0.11 & 1.39 \\
\hline Albizia sp. & 1.67 & 0.03 & 0.25 & 0.39 & 0.54 & 1.17 \\
\hline Protium serratum & 25.00 & 0.12 & 3.69 & 2.72 & 2.30 & 8.72 \\
\hline Elaeocarpus tectorius & 3.33 & 0.21 & 0.49 & 0.78 & 3.93 & 5.20 \\
\hline Syzygium cumini & 1.67 & 0.01 & 0.25 & 0.39 & 0.22 & 0.85 \\
\hline Holigarana longfolia & 5.00 & 0.19 & 0.74 & 0.78 & 3.57 & 5.09 \\
\hline Ficus racemosa & 6.67 & 0.02 & 0.99 & 1.17 & 0.43 & 2.58 \\
\hline Spondias pinnata & 3.33 & 0.10 & 0.49 & 0.78 & 1.94 & 3.21 \\
\hline Lagerstroemia speciosa & 3.33 & 0.01 & 0.49 & 0.78 & 0.14 & 1.41 \\
\hline Cinnamomum tamala & 5.00 & 0.01 & 0.74 & 0.78 & 0.21 & 1.73 \\
\hline Neolamarckia cadamba & 6.67 & 0.02 & 0.99 & 1.17 & 0.38 & 2.53 \\
\hline Albizia lebbeck & 1.67 & 0.03 & 0.25 & 0.39 & 0.51 & 1.14 \\
\hline Schima wallichii & 8.33 & 0.01 & 1.23 & 1.56 & 0.20 & 2.99 \\
\hline Carallia brachiata & 3.33 & 0.06 & 0.49 & 0.78 & 1.17 & 2.44 \\
\hline Albizia procera & 13.33 & 0.01 & 1.97 & 1.95 & 0.23 & 4.15 \\
\hline Mallotus tetracoccus & 1.67 & 0.01 & 0.25 & 0.39 & 0.22 & 0.85 \\
\hline Holarrhena antidysenterica & 23.33 & 0.02 & 3.45 & 2.33 & 0.44 & 6.23 \\
\hline Erythrina fusca & 3.33 & 0.02 & 0.49 & 0.78 & 0.32 & 1.59 \\
\hline Swietenia macrophylla & 5.00 & 0.09 & 0.74 & 0.78 & 1.66 & 3.18 \\
\hline Litsea glutinosa & 5.00 & 0.01 & 0.74 & 1.17 & 0.13 & 2.04 \\
\hline Brownlowia elata & 16.67 & 0.01 & 2.46 & 2.72 & 0.09 & 5.27 \\
\hline Azadirachta indica & 3.33 & 0.02 & 0.49 & 0.78 & 0.43 & 1.70 \\
\hline Litsea monopetala & 10.00 & 0.14 & 1.48 & 1.56 & 2.75 & 5.79 \\
\hline Aphanamixis polystachya & 8.33 & 0.01 & 1.23 & 0.78 & 0.15 & 2.16 \\
\hline Syzygium fruticosum & 6.67 & 0.02 & 0.99 & 1.17 & 0.44 & 2.59 \\
\hline Albizia odoratissima & 5.00 & 0.07 & 0.74 & 1.17 & 1.34 & 3.25 \\
\hline Tectona grandis & 3.33 & 0.06 & 0.49 & 0.78 & 1.19 & 2.46 \\
\hline Streblus asper & 3.33 & 0.01 & 0.49 & 0.39 & 0.23 & 1.11 \\
\hline Bombax insigne & 35.00 & 0.18 & 5.17 & 3.50 & 3.49 & 12.16 \\
\hline Anogeissus acuminata & 15.00 & 0.05 & 2.22 & 1.95 & 1.00 & 5.16 \\
\hline Albizia lucidior & 3.33 & 0.47 & 0.49 & 0.78 & 8.86 & 10.13 \\
\hline Mallotus philippensis & 8.33 & 0.01 & 1.23 & 1.17 & 0.23 & 2.63 \\
\hline Oroxylum indicum & 25.00 & 0.01 & 3.69 & 3.50 & 0.21 & 7.41 \\
\hline Toona ciliata & 5.00 & 0.24 & 0.74 & 0.78 & 4.63 & 6.15 \\
\hline Sterculia villosa & 6.67 & 0.05 & 0.99 & 1.17 & 1.00 & 3.15 \\
\hline Mangifera sylvatica & 5.00 & 0.01 & 0.74 & 0.78 & 0.17 & 1.69 \\
\hline Unidentified-1 & 6.67 & 0.01 & 0.99 & 0.78 & 0.17 & 1.94 \\
\hline Unidentified-2 & 3.33 & 0.01 & 0.49 & 0.78 & 0.27 & 1.54 \\
\hline Unidentified-3 & 6.67 & 0.14 & 0.99 & 1.17 & 2.57 & 4.73 \\
\hline Unidentified-4 & 15.00 & 0.01 & 2.22 & 1.95 & 0.08 & 4.24 \\
\hline Unidentified-5 & 10.00 & 0.45 & 1.48 & 1.56 & 8.55 & 11.58 \\
\hline Unidentified-6 & 1.67 & 0.19 & 0.25 & 0.39 & 3.56 & 4.20 \\
\hline Unidentified-7 & 5.00 & 0.02 & 0.74 & 0.78 & 0.29 & 1.80 \\
\hline Unidentified-8 & 1.67 & 0.37 & 0.25 & 0.39 & 6.99 & 7.62 \\
\hline Total & & & 100.00 & 100.00 & 100.00 & 300.00 \\
\hline
\end{tabular}

Note: $\mathrm{BA}=$ basal area; $\mathrm{RD}=$ relative density; $\mathrm{RF}=$ relative frequency; $\mathrm{RDo}=$ relative dominance; $\mathrm{IVI}=\mathrm{Importance}$ Value Index 


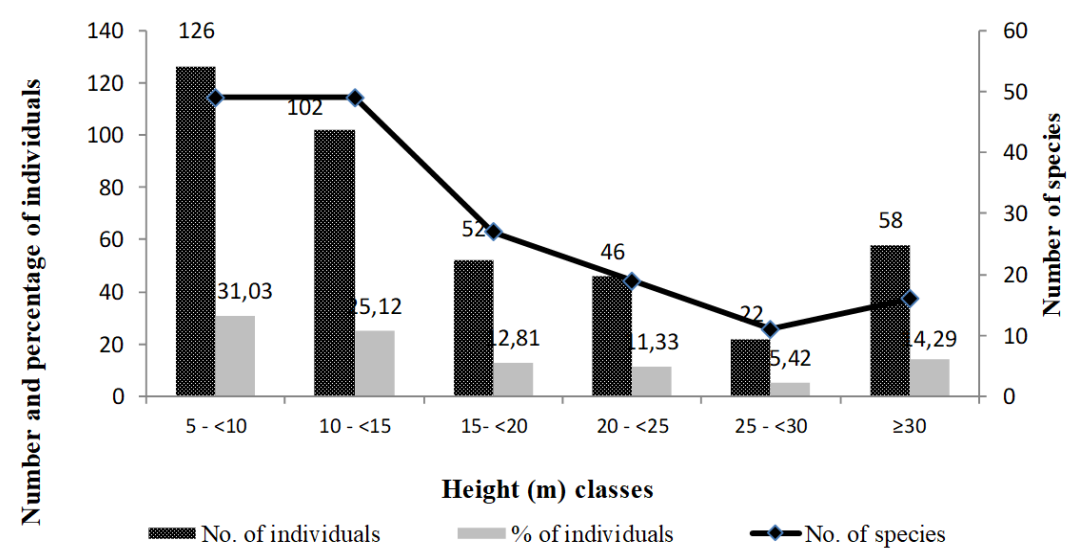

Figure 2. Distribution of tree height (m) classes at Babu Para VCF, Bandarban District, Bangladesh

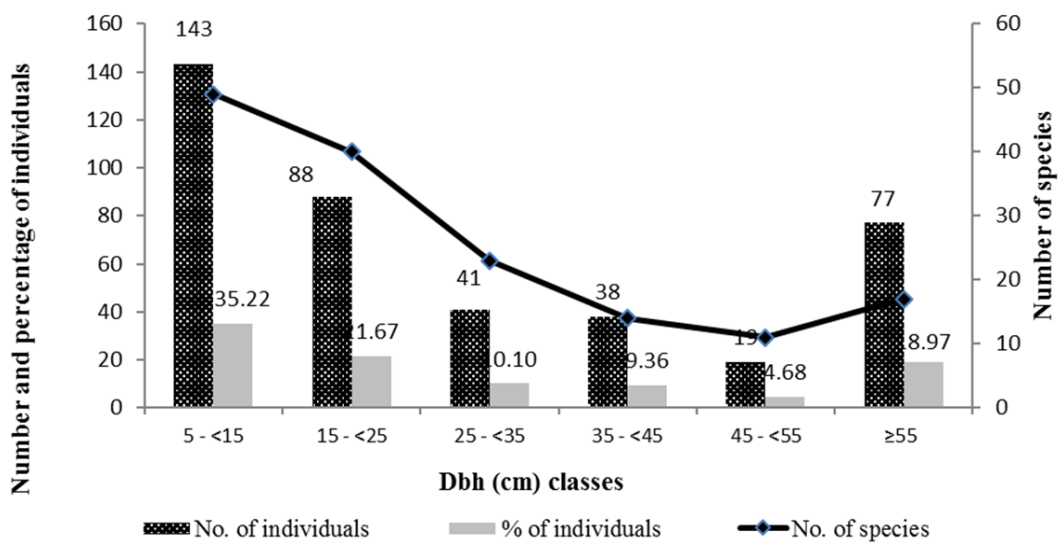

Figure 3. Distribution of tree dbh (cm) classes at Babu para VCF, Bandarban District, Bangladesh

Table 4. Biological diversity indices for recorded tree species

\begin{tabular}{lc}
\hline \multicolumn{1}{c}{ Name of the indices } & $\begin{array}{c}\text { Diversity } \\
\text { index values }\end{array}$ \\
\hline Shannon-Wiener's Diversity Index (H) & 3.94 \\
Simpson's Diversity Index (D) & 0.025 \\
Margalef's Richness Index (R) & 12.15 \\
Species Evenness Index (E) & 0.92 \\
\hline
\end{tabular}

\section{Discussion}

The sampled sites in Babu Para VCF supported 406 individuals of 74 tree species belonging to 30 families whereas Jannat et al. (2020) documented 576 individuals of 85 tree species belonging to 31 families in Renikhayong para VCF, Bandarban. Baten et al. (2010) recorded 173 floral species from the VCF in CHT. Hossain and Hossain (2014) reported 240 tree species under 61 families from Chunati Wildlife Sanctuary. A total of 182 tree species belonging to 50 families were recorded from the DDWS (Feeroz et al. 2012). Feeroz et al. (2011) reported 142 tree species belonging to 57 families from Rema-Kalenga Wildlife Sanctuary. Compared to such areas, Babu Para VCF is quite poor in terms of tree species richness. This might be caused by smaller extent (only 40 acres) of the sampled area in this study. However, Malaker et al. (2010) reported about 78 tree species from Lawachara forest. Sobuj and Rahman (2010) reported 26 tree species from Khadimnagar National Park. About 82 species under 31 families were found in Dulahazara Safari Park (Uddin and Misbahuzzaman 2007). Baten et al. (2010); Adnan and Dastidar (2011); Jashimuddin and Inoue (2012) reported that VCF shows rich biodiversity compared to governmentmanaged reserve forests in CHT and has similarities with the present findings.

In the present study, both the number of species and number of individuals were highest in the height range of 5-<10 m. Hossain and Hossain (2014) reported that maximum number of tree species was represented by the height class $3-<8 \mathrm{~cm}$ in Chunati Wildlife Sanctuary (WS). Number of species and number of individuals was found highest in the dbh range of $5-<15 \mathrm{~cm}$ in the present study which is almost similar to the findings of Nath et al. (1997). They found maximum individuals in the dbh range of 10-19.9 $\mathrm{cm}$ for the natural forests of CHT (South Forest Division).

The Shannon-Wiener's Diversity Index (3.94) found in the present study is higher than that of 2.98 in Sithapahar Reserve Forest (Nath et al. 2000) and 3.25 in Tankawati 
natural forest in Chittagong (South) Forest Division (Motaleb and Hossain 2011). The index is comparable to Shannon-Wiener's Diversity Index (4.45) found in Dhudpukuria-Dhopachori Wildlife Sanctuary (Hossain et al. 2013) and 4.27 of Garo Hills of India (Kumar et al. 2006). The Value of Shannon-Wiener's Index (3.94) and Margalef's Index (12.15) and lower value of Simpson's Index (0.025) in the present index indicate higher species diversity in Babu Para VCF of Bandarban compared to other natural forests of the country. Shannon-Wiener Index found in the present study was 3.94 which has similarities with the findings of Tripathi et al. (2004); Kumar et al. (2006); Velho and Krishnadas (2011); and Ndah et al. (2013). They found Shannon-Wiener Index within $3.50-$ 4.27 for natural forests.

Species Evenness Index was found 0.92 in the present study which is similar to the findings of Jannat et al. (2019); Tripathi et al. (2004); Ndah et al. (2013); Panda et al. (2013). They reported species Evenness Index within 0.88-0.99. However, present findings are quite higher compared with Bhuiyan et al. (2003) and Hayat et al. (2010). Simpson's index was found 0.028 which is comparable with the findings of Ndah et al. (2013) and Panda et al. (2013). However, Mishra and Garkoti (2016) differ with that.

The VCF that harbors more than 74 tree species of different habit forms indicates the importance and potentiality of the VCF for conservation and natural ecosystem. Various diversity indices, regular distribution of tree species in different height and dbh (diameter at breast height) classes indicate rich biodiversity and existence of complex ecosystem functions in the study area. VCFs are equipped with valuable medicinal plants, which help disadvantaged indigenous communities to get rid of various diseases.

From the study, it can be concluded that the management of VCF is increasingly becoming essential for the subsistence of people in the area. The management practices in VCFs are effective to sustain a balance between conservation and exploitation of forest resources. The formation of local institutions and setting of forest management practices by indigenous communities restrict users from over-exploitation of forest resources, which can be used as an influential model for managing government forests.

\section{ACKNOWLEDGEMENTS}

The authors are grateful to Tahzingdong (NGO) and local inhabitants of Bandarban District especially those who were involved in field data collection. The authors cordially acknowledge and are highly thankful to the taxonomist of Bangladesh Forest Research Institute (BFRI) and Institute of Forestry and Environmental Sciences, University of Chittagong, for identification of the plant samples.

\section{REFERENCES}

Adnan S, Dastidar R. 2011. Alienation of the lands of indigenous peoples in the Chittagong Hill Tracts of Bangladesh. Chittagong Hill Tracts Commission/International Work Group for Indigenous Affairs, Dhaka/Copenhagen.

Baten MA, Khan NA, Ahmad R, Misbahuzzaman K. 2010. Village common forests in Chittagong Hill Tracts, Bangladesh: Balance between Conservation and Exploitation. In: First International Community Forestry Conference, Unnayan Onneshan-The Innovators. Nepal, 15-18 September 2009.

Bhuiyan P, Khan ML, Tripathi RS. 2003. Tree diversity population structure in undisturbed and human-impacted stands of tropical wet evergreen forest in Arunachal Pradesh, Eastern Himalayas and India. Biodivers Conserv 12: 1753-1773. DOI: 10.1023/A:1023619017786

Chaturvedi AN, Khanna SL. 1982. Forest Mensuration. International Book Distributors, Dehra Dun, India.

Chowdhury K. 2008. Politics of identities and resources in Chittagong Hill Tracts, Bangladesh: Ethnonationalism and/or indigenous identity. Asian J Soc Sci 36: 57-78. DOI: 10.1163/156853108X267567

Feeroz MM, Hasan MK, Hossain MK. 2012. Biodiversity of protected areas of Bangladesh, Vol. 2: Dudpukuria-Dhopachari wildlife sanctuary. BioTrack, Arannayk Foundation, Dhaka, Bangladesh.

Feeroz MM, Hasan MK, Khan MMH. 2011. Biodiversity of protected areas of Bangladesh, Vol. 1: Rema-Kalenga wildlife sanctuary. BioTrack, Arannayk Foundation, Dhaka, Bangladesh.

Halim S, Roy RD. 2006. Lessons learned from the application of human rights-based approaches in the indigenous forestry sector in the Chittagong Hill Tracts, Bangladesh: A case study of the village common forest project implemented by Taungya. Taungya, Rangamati.

Hayat MA, Kudus KA, Faridah-Hanum I, Noor AA, Nazre M. 2010. Assessment of plant species diversity at Pasir Tengkorak Forest Reserve, Langkawi Island, Malaysia. J Agric Sci 2: 31-38. DOI: 10.5539/jas.v2n1p31

Hossain MA, Hossain MK, Salam MA, Rahman S. 2013. Composition and diversity of tree species in Dudpukuria-Dhopachori Wildlife Sanctuary of Chittagong (South) Forest Division, Bangladesh. Res J Pharm Biol Chem Sci 4 (2): 1447-1457.

Hossain MK, Hossain MA. 2014. Biodiversity of Chunati Wildlife Sanctuary: Flora. Arannayk Foundation and Bangladesh Forest Department. Dhaka, Bangladesh.

Jannat M, Kamruzzaman M, Hossain MK. 2019. Tree species diversity in the forest of Renikhayong para village in Bandarban, Bangladesh: a case study. J Biodivers Conserv Bioresour Manag 5 (2): 115-126. DOI: $10.3329 /$ jbcbm.v5i2.44922.

Jannat M, Kamruzzaman M, Hossain MK. 2020. Assessment of natural regeneration potential of native tree species in a community-managed forest of Bangladesh. Intl $\mathrm{J}$ Environ 9 (1): 100-114. DOI: 10.3126/ije.v9i1.27598.

Jannat M, Hossain MK, Uddin MM, Hossain MA, Kamruzzaman M. 2018. People's dependency on forest resources and contributions of forests to the livelihoods: a case study in Chittagong Hill Tracts (CHT) of Bangladesh. Intl J Sustain Dev World Ecol 2(6): 554-561. DOI: $10.1080 / 13504509.2018 .1434571$

Jashimuddin M, Inoue M. 2012. Management of village common forests in the Chittagong Hill Tracts of Bangladesh: Historical background and current issues in terms of sustainability. Open J For 2 (03): 121. DOI: 10.4236/ojf.2012.23016

Kamruzzaman M, Hossain MA, Jannat M, Hossain MK. 2018. Regeneration status of babu para Village Common Forest (VCF) in Bandarban District, Bangladesh. AASCIT J Biol 4 (1): 15-20.

Kumar A, Marcot BG, Saxena A. 2006. Tree species diversity and distribution patterns in tropical forests of Garo Hills. Curr Sci 91: 1370-1381.

Malaker JC, Rahman MM, Azad-ud-doula Prodhan AKM, Malaker SK, Khan MAH. 2010. Floristic composition of Lawachara forest in Bangladesh. Int J Expt Agric 1 (2): 1-9.

Margalef R. 1958. Temporal succession and spatial heterogeneity in phytoplankton: perspective in marine biology. University of California Press, Berkeley, CA.

Miah MD, Chowdhury MSH. 2004. Traditional Forest Utilization Practice by the Mro Tribe in the Bandarban Region, Bangladesh. Schweizerische Zeitschrift fur Forstwesen 155: 65-70. DOI: 10.3188/szf.2004.0065 
Mishra BK, Garkoti SC. 2016. Species Diversity and Regeneration Status in Sabaiya Collaborative Forest, Nepal. In: Raju N (eds) Geostatistical and Geospatial Approaches for the Characterization of Natural Resources in the Environment. Springer Cham.

Motaleb MA, Hossain MK. 2011. Assessment of tree species diversity of Tankawati natural forests, Chittagong (South) Forest Division, Bangladesh. Eco-Friendly Agric J 4 (2): 542-545.

Nath TK, Hossain MK, Alam MK. 2000. Assessment of tree species diversity of Sitapahar forest reserve, Chittagong Hill Tracts (South) Forest Division, Bangladesh. Indian For 126: 16-21.

Nath TK, Hossain MK, Alam MK. 1997. Studies on the structural composition of a natural forest of Chittagong Hill Tracts (South) Forest Division based on diameter class distribution. Chittagong University Studies Part ii: Science 21(1): 15-22. DOI 10.3923/jas.2005.227.231

Ndah NR, Andrew EE, Bechem E. 2013. Species composition, diversity and distribution in disturbed Takamanda Rainforest, South West and Cameroon. Afr J Plant Sci 7: 577-585. DOI: 10.5897/AJPS2013.1107

Panda PC, Mahapatra AK, Acharya PK, Debata AK. 2013. Plant diversity in tropical deciduous forests of Eastern Ghats, India: A landscapelevel assessment. Intl J Biodivers Conserv 5: 625-639.

Pielou EC. 1966. Species diversity and pattern diversity in the study of ecological succession. J Theor Biol 10:370-383. DOI: 10.1016/00225193(66)90133-0

Rasul G. 2007. Political ecology of degradation of forest commons in the Chittagong Hill Tracts of Bangladesh. Environ Conserv 34: 153-163. OI: $10.1017 / \mathrm{S} 0376892907003888$
Rasul G, Karki M. 2006. Political ecology of degradation of forest commons in the Chittagong Hill Tracts of Bangladesh. The Eleventh Biennial Conference of the International Association for the Study of Common Property. Bali, 19-23 June 2006.

Roy RD. 2002. Land and forest rights in the Chittagong Hill Tracts, Bangladesh. International Centre for Integrated Mountain Development.

Shannon CE, Wiener W. 1963. The Mathematical Theory of Communication. University of Illinois Press, Urbana.

Shukla RS, Chandal RS. 1980. Plant Ecology and Soil Science. S Chand and Company Ltd. Delhi-11055.

Simpson EH. 1949. Measurement of Diversity. Nature 163 (4148): 688688. DOI: $10.1038 / 163688 \mathrm{a} 0$

Sobuj NA, Rahman M. 2010. Assessment of plant diversity in Khadimnagar National Park of Bangladesh. Intl J Environ Sci 2 (1): 79-91.

Tripathi KP, Tripathi S, Selven T, Kumar K, Singh KK, Mehrotra S, Pushpangadan P. 2004. Community structure and species diversity of Saddle Peak forests in Andaman Island. Trop Ecol 45: 241-150.

Uddin SMM, Misbahuzzaman K. 2007. Tree species diversity in Dulahazara Safari Park of Bangladesh. Malays Appl Biol J 36 (2): 3340.

Velho N, Krishnadas M. 2011. Post-logging recovery of animal-dispersed trees in a tropical forest site in northeast India. Trop Conserv Sci 4: 405-419. DOI: 10.1177/194008291100400404 